\title{
Course Management System's Compatibility with Teaching Style Influences Willingness to Complete Training
}

\author{
Audrey Smith Pereira, Ph.D. \\ Fitchburg State University, Fitchburg, Massachusetts \\ Monika Maya Wahi \\ Laboure College, Milton, Massachusetts \\ Vasanta Health Science LLC, Cambridge, Massachusetts
}

\begin{abstract}
Although course management systems (CMSs) provide technology platforms that help faculty members adopt better techniques for teaching and learning, and training contributes to faculty information technology (IT) use, many higher education faculty members do not complete CMS training programs, resulting in underuse of CMSs. Therefore, the overall purpose of this research was to address how instructor perceptions influence willingness to complete IT training on CMSs, and to discern techniques university administrators can implement to improve training completion rates and, ultimately, CMS adoption rates. The basic design of the study was a crosssectional survey. Data were obtained from 102 public university faculty members who responded to an anonymous, web-based survey about their perceptions of the relative advantage, compatibility, complexity, trialability, and observability of their institution's CMS. The data were analyzed using multiple linear regression models. Compatibility, defined as the degree to which instructors perceive the CMS as being consistent with their existing values, past experiences, and current or future teaching needs, was statistically significantly associated with willingness to complete online and in-person CMS training after controlling for other factors. Major findings suggest that faculty training on the CMS is not "one size fits all." If greater use of CMSs by faculty is to be achieved, university administrators should consider compatibility of teaching style with CMS adoption when developing and promoting CMS training.
\end{abstract}

Keywords: higher education faculty members, course management system, technology adoption, educational technology, faculty training and development, diffusion of innovation theory

Pereira, A. S. \& Wahi, M.M. (2017). Course management system’s compatibility with teaching style influences willingness to complete training. Online Learning 21(1), 36-59. doi: 10.24059/olj.v21i1.763 


\section{Introduction}

Many higher education administrators offer course management systems (CMSs) to their faculty members to use in their courses (Green, 2010), and these CMSs help instructors improve teaching and learning (Tsai \& Talley, 2013; Yidana, Sarfo, Edwards, Boison, \& Wilson, 2013). However, CMS adoption rates by faculty are low (Green, 2010; Unwin et al., 2010). The lack of faculty training on information technology (IT) is one factor that contributes to low faculty IT adoption rates (deNoyelles, Cobb, \& Lowe, 2012; Goktas, Yildirim, \& Yildirim, 2009; Masalela, 2009; Smolin \& Lawless, 2011). Yet, researchers have found that many faculty members are unwilling to complete IT training (Hassan, 2011; Hurtado, Eagan, Pryor, Pereira, 2015; Whang, \& Tran, 2012). Faculty members who do not complete IT training on the CMS will be less likely to adopt the CMS, resulting in lost opportunities to increase the quality of teaching and learning at their institutions.

Therefore, this study examined faculty members' perceptions of their organization's CMS that may influence their willingness to complete IT training on the CMS. The research was grounded in components of Rogers' (2003) diffusion of innovations (DOI) theory. According to Rogers (2003), five perceived attributes of an innovation partially explain technology adoption: relative advantage, compatibility, complexity, trialability, and observability. Rogers asserted that perceived relative advantage, compatibility, trialability, and observability of an innovation relates positively to its adoption rate, whereas an innovation's perceived complexity has a negative influence on its adoption.

Research has shown that the quality of teaching and learning increases if faculty members more broadly adopt their organization's CMS (Tsai \& Talley, 2013; Yidana et al., 2013). Research has also shown that faculty training on their CMS improves faculty adoption of these systems (deNoyelles et al., 2012; Hixon, Buckenmeyer, Barczyk, Feldman, \& Zamojski, 2012; McBride \& Thompson, 2011), but unfortunately, the rate of faculty training on CMSs is low (Hassan, 2011; Hurtado et al., 2012; Pereira, 2015). Therefore, increasing faculty willingness to complete CMS training on their organization's CMS, the topic of this research, should ultimately lead to higher CMS adoption rates by faculty members, and consequently, improved quality of teaching and learning in higher education.

This paper will first provide a review of the literature associated with faculty adoption and willingness to complete training on educational technology, including CMSs. Next, the research questions and methodology for the study will be described. Results will then be

presented, followed by a discussion, which will include recommendations for administrative approaches to improving CMS training completion rates among faculty members, as well as recommendations for future research.

\section{Review of Related Literature}

The literature indicates that the use of IT positively contributes to teaching and learning in the higher education classroom (Archambault, Wetzel, Foulger, \& Williams, 2010; Newhouse, Buckley, Grant, \& Idzik, 2013). Consequently, CMSs, including Blackboard, have been 
developed to improve the teaching and learning process; to facilitate this goal, they also offer online course management tools (Blackboard, Inc., 2017). This suggests that use of CMSs, such as Blackboard, in the higher education classroom has a considerable potential to increase the quality of teaching and learning. This contention is supported by research conducted by Yidana et al. (2013) who found that learning was improved through the provision of a CMS that permitted students to control their learning process and learn independently, as well as research conducted by Tsai and Talley (2013) who reported that foreign language students' reading comprehension improved when they used a CMS. Also, Unal and Unal (2011) described a study in which students rated different teaching and learning functions within two CMSs (Blackboard and Moodle) but that, regardless of the CMS, the students rated these teaching and learning functions highly, indicating that students were ready to adopt CMSs. Additionally, from their research on course design and delivery elements that affect student satisfaction, Simon, Jackson, and Maxwell (2013) suggested that CMSs are valuable scholastic tools, in that they can represent “a rigorous alternative or supplement to traditional instruction” (p. 112). However, they also concluded that professors should not be replaced by CMSs in the learning process.

Although researchers have found that IT has the potential to improve the quality of teaching and learning in higher education (Archambault et al., 2010; Newhouse et al., 2013), and CMSs are now commonly present in higher education (Green, 2010) many faculty members are slow to integrate IT (and CMSs) into their classrooms (Abrahams, 2010; Bothma \& Cant, 2011; Unwin et al., 2010; Yohon \& Zimmerman, 2006) and resist using IT for teaching and learning (Hicks, 2011). Additionally, faculty members are more proficient in basic rather than high-level technologies (Allen \& Seaman, 2012; Chitiyo \& Harmon, 2009; Kinuthia, 2005; Rocca, 2010), and Allen and Seaman (2012) as well as Ertmer and Ottenbreit-Lefwich (2010) suggested that faculty are more likely to use IT to facilitate traditional rather than new instructional techniques. Also, although the literature suggests that faculty IT training is one factor that influences adoption of IT in the classroom (deNoyelles et al., 2012; Goktas et al., 2009; Kidd, 2010; Masalela, 2009; McBride \& Thompson, 2011; Porter, 2011; Potter \& Rockinson-Szapkiw, 2012; Samarawickrema \& Stacey, 2007; Smolin \& Lawless, 2011), it also suggests that many faculty members are unwilling to complete formal IT training (Hassan, 2011; Hurtado et al., 2012; Pereira, 2015; Yohon \& Zimmerman, 2006).

Because of the low faculty adoption rates (Green, 2010; Unwin et al., 2010) and costs associated with implementing a CMS at higher education organizations, many researchers have focused on studying barriers to CMS adoption, as well as studying factors that may improve faculty adoption rates (Bennett \& Bennett, 2003; Green, 2010; Keesee \& Shepard, 2011; Mallinson \& Krull, 2013; Samarawickrema \& Stacey, 2007; West, Waddoups, \& Graham, 2007). For example, Bennett and Bennett (2003) studied 20 higher education faculty members and concluded that workshop-based training improves faculty attitudes toward the CMS, and West et al. (2007) asserted that this indicates that faculty training increases the probability of CMS adoption.

Based on this body of research related to barriers to IT adoption in general and CMS adoption specifically, and factors that may influence adoption, some writers have recommended improvements to faculty IT training, as a way to improve instructional IT adoption. This is because offering higher-quality training may result in increased faculty willingness to complete 
the training. These recommendations include the following: offering pedagogical as well as technological training (Calderon et al., 2012; Iorio, Kee, \& Decker, 2012; Kidd, 2010; Mark, Thadani, Santandreu Calonge, Pun, \& Chiu, 2011; Samarawickrema \& Stacey, 2007); developing research-based technology training programs (Onyia \& Onyia, 2011); ensuring IT training is relevant to faculty needs (Kidd, 2010) and is accessible (Keengwe, Kidd, \& KyeiBlankson, 2009); requiring training as part of employment obligations (Onyia \& Onyia, 2011); aligning IT training with institutional policies and procedures (Korr, Derwin, Greene, \& Sokoloff, 2012); and offering in-person as well as online training (Kidd, 2010).

Scholars have also researched the influence of CMS training specifically (Allen \& Seaman, 2012; Bennett \& Bennett, 2003; Samarawickrema \& Stacey, 2007). Samarawickrema and Stacey (2007) asserted that CMS training is more valuable to faculty members if it is applicable, appropriate, timely, and relevant. Further, Allen and Seaman (2012) found that while administrators rated their CMS training offerings as high quality, faculty attitudes about the CMS training were less positive.

However, fewer studies focused on the factors that influence instructors' willingness to attend, and presumably complete, IT training (on the institution's CMS or otherwise). This body of literature indicates that the following factors influence faculty willingness to attend or complete training: professional growth (Kinuthia, 2005); time away from duties (Kinuthia, 2005; Sandford, Dainty, Belcher, \& Frisbee, 2011); free hardware/software (Kinuthia, 2005); timing of training programs (Roman, Kelsey, \& Lin, 2010; Sandford et al., 2011), skill level (Chen et al., 2000); travel distance (Sandford et al., 2011); teaching experience (Sandford et al., 2011); and specific pedagogical competencies (Carril, Sanmamed, \& Sellés, 2013). These studies also indicated that incentives, including monetary rewards, release time, and positive impacts on tenure and promotion encourage faculty to attend IT training (Kinuthia, 2005; Sandford et al., 2011). These results should be considered alongside studies that found that incentives are an important factor in improving faculty IT adoption rates (Allen \& Seaman, 2012; Al-Senaidi, Lin, \& Poirot, 2009; Aremu, Fakolujo, \& Oluleye, 2013; Keengwe et al., 2009; Masalela, 2009; McKissic, 2012; Yidana et al., 2013).

The current state of the literature on this subject suggests that research on factors that improve higher education faculty's willingness to complete CMS training, both online and inperson, are lacking. Thus, this study aims to fill this important gap in the literature. Although higher education administrators invest considerable portions of their institutions' budgets in providing high-quality CMS services (Green, 2010) and CMS training (Meyer, 2014; Pereira, 2015), unfortunately, many faculty members are unwilling to complete the CMS training offered (Hassan, 2011; Hurtado et al., 2012; Pereira, 2015). This contributes to low faculty CMS adoption rates, resulting in lower quality teaching and learning than would be possible with CMS adoption, and lost opportunities to improve student learning experiences in higher education.

This study explored how higher education faculty perceptions of the relative advantage, compatibility, complexity, trialability, and observability (as defined by Rogers' (2003) DOI theory) of their institution's CMS influence their willingness to complete online and in-person IT training on use of the CMS. Specific research questions were the following: (a) What is the relative contribution of faculty perceptions of the relative advantage of using their institution's 
CMS in teaching and learning to their willingness to complete online and in-person IT training on the CMS? (b) What is the relative contribution of faculty perceptions of the compatibility of using their institution's CMS to their willingness to complete online and in-person IT training on the CMS? (c) What is the relative contribution of faculty perceptions of the complexity of the CMS to their willingness to online and in-person IT training on the CMS? (d) What is the relative contribution of faculty perceptions of the trialability of their CMS to their willingness to complete online and in-person IT training on the CMS? (e) and What is the relative contribution of faculty perceptions of the observability of their CMS to their willingness to complete online and in-person IT training on the CMS?

\section{Methods}

\section{Study Population/Sampling}

All 392 full-time and part-time faculty members who taught undergraduate and graduate courses at Fitchburg State University (FSU) in Fitchburg, Massachusetts, a public university in the northeast United States, were invited to participate in an anonymous, web-based survey in late 2014. The survey included questions about their demographics, perceptions of their institution's CMS, and willingness to complete CMS training. The response rate was 29\%.After exclusions for ineligible responses, 102 surveys were used for data analysis, yielding a revised response rate of $26 \%$.

Forty-seven percent of the respondents were male and $46 \%$ female, while eight respondents did not identify their gender. At FSU, the following ranks are available: instructor, assistant professor, associate professor, and full professor (called "professor"). The instructor level can be occupied by full-time faculty, but is typically the level assigned to adjunct and parttime faculty. In the sample, 26\% were instructors, $24 \%$ assistant professors, $23 \%$ associate professors, and 27\% professors. Respondents taught in the following departments: 34\% Science, Technology, Engineering, and Mathematics; 16\% Social Science, Economics, History, and Political Science; 15\% Education, Communication, and Game Design; and 36\% taught in other departments, including Business Administration, English Studies, Industrial Technology, Interdisciplinary Studies, and Nursing.

\section{Data Collection}

After obtaining approval from the appropriate Institutional Review Boards for the Protection of Human Subjects in Research (IRB), data were collected anonymously using a public link through SurveyMonkey (SurveyMonkey, 2015). The survey questions that measured perceptions of the CMS were considered independent variables in this study, and were based on subscales developed by Keesee (2010). Keesee (2010) named her instrument the CMS Diffusion of Innovations Survey (CMS-DOIS). Perceptions of the relative advantage, compatibility, complexity, trialability, and observability were measured using statements asking respondents to rate them on a 5-point Likert scale where $1=$ strongly disagree, $2=$ disagree, $3=$ undecided/neutral, $4=$ agree, and 5 = strongly agree. To score each subscale, the mean of the Likert scale questions were taken (for number of questions per subscale, see Table 1). The survey questions that measured willingness to complete in-person and online CMS training were considered dependent variables, and were developed specifically for this study (Pereira, 2015). These were measured with two statements (one for online training and one for in-person training) 
using a 5-point Likert scale, where $1=$ not at all willing, $2=$ somewhat unwilling, $3=$ neither willing nor unwilling, 4 = somewhat willing, and 5 = very willing (see Table 1 ).

Table 1

Survey Question Origins, Subscale Definitions, Number of Items, Cronbach's Alpha, and Sample Questions

\begin{tabular}{|c|c|c|c|c|c|}
\hline $\begin{array}{l}\text { Instrument } \\
\text { Name or } \\
\text { Source }\end{array}$ & $\begin{array}{l}\text { Subscale } \\
\text { Name }\end{array}$ & $\begin{array}{l}\text { Subscale } \\
\text { Definition* }\end{array}$ & $\begin{array}{l}\text { Number } \\
\text { of Items }\end{array}$ & $\begin{array}{l}\text { Cronbach's } \\
\text { Alpha }\end{array}$ & $\begin{array}{l}\text { Example Survey } \\
\text { Question }\end{array}$ \\
\hline $\begin{array}{l}\text { CMS- } \\
\text { DOIS }\end{array}$ & $\begin{array}{l}\text { Relative } \\
\text { advantage }\end{array}$ & $\begin{array}{l}\text { The degree to which } \\
\text { faculty members perceive } \\
\text { that incorporating the use } \\
\text { of their institution's CMS } \\
\text { in teaching and learning } \\
\text { is better than their current } \\
\text { method. }\end{array}$ & 15 & 0.939 & $\begin{array}{l}\text { Based on my } \\
\text { experiences with the } \\
\text { Blackboard CMS, I } \\
\text { think using the } \\
\text { Blackboard CMS } \\
\text { enables (would enable) } \\
\text { me to significantly } \\
\text { improve the overall } \\
\text { quality of my teaching. }\end{array}$ \\
\hline $\begin{array}{l}\text { CMS- } \\
\text { DOIS }\end{array}$ & Compatibility & $\begin{array}{l}\text { The degree to which } \\
\text { faculty members perceive } \\
\text { the CMS as being } \\
\text { consistent with their } \\
\text { existing values, past } \\
\text { experiences, and current } \\
\text { or future teaching needs. }\end{array}$ & 10 & 0.821 & $\begin{array}{l}\text { Based on my } \\
\text { experiences with the } \\
\text { Blackboard CMS, I } \\
\text { think using the } \\
\text { Blackboard CMS fits } \\
\text { (would fit) well with my } \\
\text { teaching style. }\end{array}$ \\
\hline $\begin{array}{l}\text { CMS- } \\
\text { DOIS }\end{array}$ & Complexity & $\begin{array}{l}\text { The degree to which } \\
\text { faculty members perceive } \\
\text { the CMS as relatively } \\
\text { difficult to understand } \\
\text { and use. }\end{array}$ & 10 & 0.916 & $\begin{array}{l}\text { Based on my } \\
\text { experiences with the } \\
\text { Blackboard CMS, I } \\
\text { think learning to use the } \\
\text { Blackboard CMS is } \\
\text { (would be) easy for me. }\end{array}$ \\
\hline $\begin{array}{l}\text { CMS- } \\
\text { DOIS }\end{array}$ & Trialability & $\begin{array}{l}\text { The degree to which } \\
\text { faculty members perceive } \\
\text { that they may experiment } \\
\text { with the CMS before they } \\
\text { decide to incorporate it } \\
\text { into their instruction. }\end{array}$ & 7 & 0.767 & $\begin{array}{l}\text { Based on what I know } \\
\text { right now, I think I was } \\
\text { (am) permitted to use } \\
\text { the Blackboard CMS on } \\
\text { a trial basis long enough } \\
\text { to see what it could/can } \\
\text { do. }\end{array}$ \\
\hline $\begin{array}{l}\text { CMS- } \\
\text { DOIS }\end{array}$ & Observability & $\begin{array}{l}\text { The degree to which } \\
\text { faculty members perceive } \\
\text { the results of use of the } \\
\text { CMS to be visible to } \\
\text { others. }\end{array}$ & 6 & 0.762 & $\begin{array}{l}\text { Based on what I know } \\
\text { right now, I think I have } \\
\text { observed how other } \\
\text { teachers are using the } \\
\text { Blackboard CMS in } \\
\text { their teaching. }\end{array}$ \\
\hline $\begin{array}{l}\text { Pereira } \\
2015\end{array}$ & $\begin{array}{l}\text { Willingness to } \\
\text { complete } \\
\text { online } \\
\text { Blackboard } \\
\text { training }\end{array}$ & $\begin{array}{l}\text { At time of survey, over } \\
\text { the next 12-month period, } \\
\text { how willing faculty } \\
\text { members were to } \\
\text { complete any Blackboard } \\
\text { CMS online training } \\
\text { offered by FSU. }\end{array}$ & 1 & NA & $\begin{array}{l}\text { Over the next } 12 \text {-month } \\
\text { period, how willing are } \\
\text { you to complete any } \\
\text { Blackboard CMS online } \\
\text { training module(s) } \\
\text { offered by FSU? }\end{array}$ \\
\hline $\begin{array}{l}\text { Pereira } \\
2015\end{array}$ & $\begin{array}{l}\text { Willingness to } \\
\text { complete in- } \\
\text { person } \\
\text { Blackboard } \\
\text { training }\end{array}$ & $\begin{array}{l}\text { At time of survey, over } \\
\text { the next 12-month period, } \\
\text { how willing faculty } \\
\text { members were to } \\
\text { complete any Blackboard } \\
\text { CMS in-person training } \\
\text { offered by FSU. }\end{array}$ & 1 & NA & $\begin{array}{l}\text { Over the next } 12 \text {-month } \\
\text { period, how willing are } \\
\text { you to complete any } \\
\text { Blackboard CMS face- } \\
\text { to-face training offered } \\
\text { by FSU? }\end{array}$ \\
\hline
\end{tabular}

Note: * Based on Rogers' (2003) classifications of the five perceived attributes of an innovation. 
Demographic information was also collected, as this information has been shown to have the potential to mediate the relationship between the dependent variables and independent variables (Allen \& Seaman, 2012; Al-Senaidi et al., 2009; Ertmer \& Ottenbreit-Leftwich, 2010, Hurtado et al, 2012; Keengwe et al., 2009; Keesee, 2010; Onyia \& Onyia, 2011; Yidana et al., 2013). These mediating variables were gender, age, department, tenure status, rank, length of CMS use, and level of CMS expertise (see Table 2 for mediating variable definitions).

Table 2

Mediating Variable Definitions

\begin{tabular}{|c|c|c|c|c|}
\hline Mediating Var & Measurement & Levels & Definition & Descriptive Analysis Classification \\
\hline Gender & Categories & $\begin{array}{l}\text { Male } \\
\text { Female } \\
\text { Other/refused }\end{array}$ & $\begin{array}{l}\text { Gender at time of } \\
\text { survey }\end{array}$ & Same as levels \\
\hline Age & Categories & $\begin{array}{l}20-29 \\
30-39 \\
40-49 \\
50-59 \\
60-69 \\
70-79 \\
80+\end{array}$ & Age at time of survey & $\begin{array}{l}\text { Collapsed into the following } \\
\text { groups due to low sample size: } \\
20-39 \\
40-49 \\
50-59 \\
60-69 \\
70+\end{array}$ \\
\hline Department & Categories & $\begin{array}{l}\text { Science, Technology, } \\
\text { Engineering, and Math } \\
\text { Social Science } \\
\text { Education } \\
\text { Economics, History, and } \\
\text { Political Science } \\
\text { Communications, } \\
\text { Game Design } \\
\text { All other departments }\end{array}$ & $\begin{array}{l}\text { Primary department } \\
\text { where faculty worked } \\
\text { at time of survey }\end{array}$ & $\begin{array}{l}\text { Collapsed into the following } \\
\text { groups due to low sample size: } \\
\text { Science Technology, Engineering, } \\
\text { and Math } \\
\text { Social Science, Economics, } \\
\text { History, and Political Science } \\
\text { Education, Communication, and } \\
\text { Game Design } \\
\text { Other }\end{array}$ \\
\hline Tenure Status & Categories & $\begin{array}{l}\text { Full-time tenured } \\
\text { Full-time tenure-track } \\
\text { Full-time nontenure- } \\
\text { track } \\
\text { Part-time }\end{array}$ & $\begin{array}{l}\text { Faculty tenure status at } \\
\text { time of survey }\end{array}$ & $\begin{array}{l}\text { Collapsed into the following } \\
\text { groups due to low sample size: } \\
\text { Full-time tenured } \\
\text { Full-time tenure-track } \\
\text { Full-time and part-time nontenure- } \\
\text { track }\end{array}$ \\
\hline Rank & Categories & $\begin{array}{l}\text { Instructor } \\
\text { Assistant Professor } \\
\text { Associate Professor } \\
\text { Professor } \\
\text { Other (please specify) }\end{array}$ & $\begin{array}{l}\text { Faculty rank at time of } \\
\text { survey }\end{array}$ & $\begin{array}{l}\text { Collapsed into the following } \\
\text { groups after analyzing "other" } \\
\text { responses: } \\
\text { Instructor } \\
\text { Assistant Professor } \\
\text { Associate Professor } \\
\text { Professor }\end{array}$ \\
\hline $\begin{array}{l}\text { Length of CMS } \\
\text { use }\end{array}$ & Years & $\begin{array}{l}0-30 \\
(0 \text { for less than } 1 \text { year } \\
\text { Or if faculty did not use } \\
\text { the CMS })\end{array}$ & $\begin{array}{l}\text { Number of years } \\
\text { faculty had used the } \\
\text { CMS at time of survey }\end{array}$ & Same as levels \\
\hline
\end{tabular}




\begin{tabular}{lllll}
\hline Mediating Var & Measurement & Levels & Definition & Descriptive Analysis Classification \\
\hline Level of CMS & Likert Scale & $1=$ none & Faculty level of & Same as levels \\
expertise & & $2=$ little & expertise using CMS & \\
& & 3 = adequate & at time of survey & \\
& & & \\
& & & & \\
& & & & \\
& & & & \\
\end{tabular}

The survey was administered during a two-week period in October 2014. To ensure anonymity, the survey was accessed via a publicly available, universal link provided in e-mail to each faculty member. One week prior to survey administration, the university's chief information officer sent the faculty list an e-mail with details about the study. In addition, a reminder e-mail with the survey link was sent one week prior to the survey close date.

\section{Data Analysis}

After downloading the data from SurveyMonkey, subscales for the CMS-DOIS instrument were scored using SPSS (SPSS, n.d.). The subscales were found to be internally consistent through a Cronbach's alpha analysis (see Table 2). The values ranged from .762 to .939 , which are considered reliable. The questions used to measure willingness to complete inperson and online training were found to have convergent validity with actual training participation (Pereira, 2015). Specifically, answers to questions on intention to complete online and in-person CMS training in the next 12 months were correlated with self-reports of training completion in the previous 12 months. The data indicated a trend that the more willing a person was to complete training, the more likely they were to have completed at least one training session over the previous 12 months.

Descriptive statistics were analyzed for the sample overall and separately for willingness to complete online versus in-person training. Means and distributions of continuous variables were considered, as were correlations.

To address the research questions, two separate analyses of variance (ANOVA) and linear regression models were developed, one to assess the association of the independent variables with the dependent variable "willingness to complete online training," and the other to assess the association of the independent variables with the dependent variable "willingness to complete in-person training." Mediating variables were entered as independent variables in the model to control for their potential influence on the dependent variable.

A best-subsets modeling procedure was followed (Hosmer, Borko, \& Lemeshow, 1989; King, 2003). The best-subsets modeling approach is a method of selecting optimal predictor variables for a dependent variable, typically a binary one (Hosmer et al., 1989), but the procedure can be used in linear regression with a continuous dependent variable (King, 2003). The purpose of applying the best-subsets approach in this study was to use a data-driven rather than intuitive method of selecting an optimal set of predictor variables for the final model.

\section{Results}

Table 3 provides descriptive statistics for the faculty sample of $n=102$ with respect to categorical, demographic characteristics. 
Table 3

Descriptive Statistics for Categorical Variables

\begin{tabular}{|c|c|c|c|c|}
\hline Category & Levels & $\mathrm{n}(\%)$ & $\begin{array}{l}\text { Online Willingness } \\
(M, S D)\end{array}$ & $\begin{array}{l}\text { In-person Willingness } \\
(M, S D)\end{array}$ \\
\hline All & All & $102,(100 \%)$ & $3.52,(1.31)$ & 3.46, (1.32) \\
\hline \multirow[t]{3}{*}{ Gender } & Male & 48, (47\%) & $3.27,(1.35)$ & $3.42,(1.18)$ \\
\hline & Female & $46,(45 \%)$ & $3.80,(1.22)$ & $3.50,(1.46)$ \\
\hline & Other & $8,(8 \%)$ & 3.38, (1.41) & $3.50,(1.41)$ \\
\hline \multirow[t]{5}{*}{ Age Group } & 20-39 years & 19, (19\%) & $3.58,(1.22)$ & 3.16, (1.34) \\
\hline & 40-49 years & $22,(22 \%)$ & 3.41, (1.33) & $3.41,(1.40)$ \\
\hline & 50-59 years & $25,(25 \%)$ & $3.64,(1.25)$ & $3.52,(1.29)$ \\
\hline & $60+$ years & $21,(21 \%)$ & $3.62,(1.40)$ & 3.86, (1.2) \\
\hline & Refused & $15,(15 \%)$ & $3.27,(1.49)$ & $3.27,(1.39)$ \\
\hline \multirow[t]{3}{*}{ Tenure Status } & Full-time Tenured & $46,(45 \%)$ & $3.22,(1.33)$ & $3.39,(1.31)$ \\
\hline & $\begin{array}{l}\text { Full-time Tenure-track } \\
\text { Full time and Part-time }\end{array}$ & $24,(24 \%)$ & 3.46, (1.32) & $3.42,(1.38)$ \\
\hline & Nontenure-track & 32, (31\%) & $4.00,(1.16)$ & $3.59,(1.32)$ \\
\hline \multirow[t]{4}{*}{ Rank } & Instructor & $27,(26 \%)$ & $4.26,(0.94)$ & $3.78,(1.37)$ \\
\hline & Assistant Professor & $24,(24 \%)$ & $3.63,(1.35)$ & $3.42,(1.38)$ \\
\hline & Associate Professor & 23, (23\%) & $3.00,(1.31)$ & $3.13,(1.29)$ \\
\hline & Professor & $28,(27 \%)$ & $3.14,(1.3)$ & 3.46, (1.23) \\
\hline \multirow[t]{4}{*}{ Department } & STEM & 35, (34\%) & 3.31, (1.37) & $3.40,(1.29)$ \\
\hline & SEHP & $16,(16 \%)$ & $3.5,(0.97)$ & $3.81,(1.05)$ \\
\hline & ECG & $15,(15 \%)$ & $4.00,(1.31)$ & $3.47,(1.41)$ \\
\hline & Other & $36,(35 \%)$ & 3.53, (1.38) & 3.36, (1.44) \\
\hline
\end{tabular}

Note: Online Willingness = willingness to complete online CMS training, In-person Willingness = willingness to complete in-person CMS training. STEM = Science, Technolgy, Engineering, and Mathmatics. SEHP = Social Science, Economics, History, and Political Science. ECG = Education, Communication, and Game Design. Other includes Business Administration, English Studies, Industrial Technology,

Interdisciplinary Studies, and Nursing.

As indicated in Table 3, mean willingness to complete training fell mostly between 3 and 4, which is a small range. Females had a higher mean willingness to complete both online (3.80 vs. 3.27) and in-person training (3.50 vs. 3.42) than males. In most cases, older age levels were more willing to complete training, with the exception of the 40-49 level who were less likely to complete online training than the other levels $(20-39$ years $=3.58,40-49$ years $=3.41,50-59$ years $=3.64$, and $60+$ years $=3.62$ ). Additionally, faculty members at earlier stages or not on the tenure track were more willing to complete training, especially in-person training (full-time tenured $=3.39$, full-time tenure-track $=3.42$, full-time and part-time non-tenure-track $=3.59$ ). Likewise, in general, lower ranks expressed higher mean levels of willingness to complete training, excluding professors who were more willing to complete training than associate professors (online willingness: instructor $=4.26$, assistant professor $=3.63$, associate professor $=$ 3.00 , professor $=3.14$; in-person willingness: instructor $=3.78$, assistant professor $=3.42$, associate professor $=3.13$, professor $=3.46)$. Finally, members of the Education, 
Communication, and Game Design departments were much more willing to complete online training while members of the Social Science, Economics, History, and Political Science departments were much more willing to complete in-person training than the other departments (online willingness: Science, Technology, Math, and Science $=3.31$, Social Science, Economics, History, and Political Science $=3.5$, Education, Communications, and Game Design = 4.00, Other, including Business Administration, English Studies, Industrial Technology, Interdisciplinary Studies, and Nursing = 3.53; in-person willingness: Science, Technology, Mathematics, and Science $=3.40$, Social Science, Economics, History, and Political Science = 3.81, Education, Communications, and Game Design $=3.47$, Other, including Business Administration, English Studies, Industrial Technology, Interdisciplinary Studies, and Nursing = 3.36).

Table 4 provides summary statistics for the continuous variables.

Table 4

Summary Statistics for Continuous Variables

\begin{tabular}{lll}
\hline Variable & $\mathrm{M}^{*}$ & $\mathrm{SD}$ \\
\hline Online Willingness & 3.52 & 1.31 \\
In-person Willingness & 3.46 & 1.32 \\
Relative Advantage & 3.58 & 0.77 \\
Compatibility & 3.66 & 0.73 \\
Complexity & 3.66 & 0.78 \\
Trialability & 3.36 & 0.70 \\
Observability & 3.48 & 0.72 \\
Length use & 6.16 & 4.22 \\
Level expertise & 3.26 & 1.04
\end{tabular}

Note: $\mathrm{N}=102$. Online Willingness = willingness to complete online CMS training and In-person Willingness = willingness to complete in-person CMS training. *Length of use measured as discrete numerical variable ranging from 0 and 30 years, where 0 = less than 1 year or no use. Other variables measured on 5-point Likert scales.

As indicated in Table 4, the mean for the continuous variables that measured faculty perceptions of the CMS (independent variables) fell in a small range, between 3.36 and 3.66. Most of the independent variables had low to moderate positive correlations with each other, apart from relative advantage and compatibility, which were highly correlated with each other (see Table 5). The dependent variables (online and in-person willingness) were highly correlated with each other. Additionally, the dependent variables had low positive correlations with length of use and expertise level, excepting the correlation between in-person willingness and expertise level which was negative. 
Table 5

\section{Correlation Matrix}

\begin{tabular}{lccccccccc}
\hline Variable & 1 & 2 & 3 & 4 & 5 & 6 & 7 & 8 & 9 \\
\hline 1. Online will & 1.000 & $.709^{*}$ & $.443^{* *}$ & $.432^{* *}$ & $.241^{*}$ & .173 & .077 & .041 & .076 \\
2. In-person will & $.709^{* *}$ & 1.000 & $.299^{* *}$ & $.290^{* *}$ & .035 & .088 & .023 & .088 & -.058 \\
4. Relative adv & $.443^{* *}$ & $.299^{* *}$ & 1.000 & $.807^{* *}$ & $.564^{* *}$ & $.270^{* *}$ & $.373^{* *}$ & $.367^{* *}$ & $.299^{* *}$ \\
5. Compatibility & $.432^{* *}$ & $.290^{* *}$ & $.807^{* *}$ & 1.000 & $.578^{* *}$ & $.233^{* *}$ & $.322^{* *}$ & $.370^{* *}$ & $.367^{* *}$ \\
6. Complexity & $.241^{*}$ & .035 & $.564^{* *}$ & $.578^{* *}$ & 1.000 & $.379^{* *}$ & $.373^{* *}$ & $.546^{* *}$ & $.593^{* *}$ \\
7. Trialability & .173 & .088 & $.270^{* *}$ & $.233^{* *}$ & $.379^{* *}$ & 1.000 & $.527^{* *}$ & .169 & $.217^{*}$ \\
8. Observability & .077 & .023 & $.373^{* *}$ & $.322^{* *}$ & $.373^{* *}$ & $.527^{* *}$ & 1.000 & $.378^{* *}$ & $.400^{* *}$ \\
9. Length & .041 & .008 & $.367^{* *}$ & $.370^{* *}$ & $.546^{* *}$ & .169 & $.378^{* *}$ & 1.000 & $.170^{* *}$ \\
10. Expert & .076 &. .058 & $.299^{* *}$ & $.367^{* *}$ & $.593^{* *}$ & $.217^{*}$ & $.400^{* *}$ & $.170^{* *}$ & 1.000 \\
\hline
\end{tabular}

Note: $N=102$. Online willingness = willingness to complete online CMS training, In-person willingness =

willingness to complete in-person CMS training. ${ }^{*} p<.05 .{ }^{* *} p<.01$.

Tables 6 and 7 present the ANOVA and linear regression results for the dependent variable "willingness to complete online training."

Table 6

Analysis of Variance for Predictors of Willingness to Complete Online Training

\begin{tabular}{lccccc}
\hline & Sum of & df & Mean Square & F & Sig. \\
\hline Squares & 53.534 & 9 & 5.948 & 4.563 & .000 \\
Regression & 119.927 & 92 & 1.304 & & \\
Total & 173.461 & 101 & & & \\
\hline
\end{tabular}

Note: Dependent variable measurement: Willingness to complete online CMS training.

Table 7

Predictors of Willingness to Complete Online Training

\begin{tabular}{lcccc}
\hline Predictor & Beta $(\beta)$ & $t$ statistic & $p$-value & VIF \\
\hline $\begin{array}{l}\text { Independent variables } \\
\quad \text { Compatibility }\end{array}$ & .490 & 5.451 & .000 & 1.075 \\
$\begin{array}{l}\text { Mediating variables } \\
\text { Department }\end{array}$ & & & & \\
$\quad$ SEHP & .117 & 1.176 & .243 & 1.319 \\
$\quad$ CGE & .452 & 3.794 & .000 & 1.889 \\
$\quad$ Other & .221 & 2.079 & .040 & 1.506 \\
Age & & & & \\
$\quad$ 20-39 years & .066 & .617 & .539 & 1.527 \\
$\quad$ 40-49 years & -.010 & -.087 & .931 & 1.726 \\
60+ years & -.033 & -.307 & .759 & 1.580 \\
$\quad$ Refused & -.105 & -.999 & .321 & 1.461
\end{tabular}


Interaction variables

Note: Dependent variable is willingness to complete online training. SEHP = Social Science, Economics, History, and Political Science. ECG = Education, Communication, and Game Design. Other includes Business Administration, English Studies, Industrial Technology, Interdisciplinary Studies, and Nursing.

The ANOVA was statistically significant $(F=4.563$ at $9 \mathrm{df} ., p=0.000)$, so the model was interpreted. After modeling, only the perception of compatibility, defined as the degree to which faculty members perceive the CMS as consistent with their existing values, past experiences, and current or future teaching needs, was significantly positively associated with willingness to complete training online (standardized $\beta=0.490, p=0.000$ ).

Tables 8 and 9 present the ANOVA and linear regression results for the dependent variable "willingness to complete in-person training."

Table 8

Analysis of Variance for Predictors of Willingness to Complete In-person Training

\begin{tabular}{lccccc}
\hline & Sum of & df & Mean Square & F & Sig. \\
\hline Squares & 49.284 & 15 & 3.286 & 2.242 & .010 \\
Regression & 126.059 & 86 & 1.466 & & \\
Total & 175.343 & 101 & & & \\
\hline
\end{tabular}

Note: Dependent variable measurement: Willingness to complete in-person person training.

Table 9

Predictors of Willingness to Complete In-person Training

\begin{tabular}{lcccc}
\hline Predictor & Beta $(\beta)$ & $t$ statistic & $p$-value & VIF \\
\hline Independent variables & & & & \\
$\quad$ Compatibility & .242 & 2.469 & .016 & 1.152 \\
Mediating variables & & & & \\
$\quad$ Tenure Status & & & & \\
$\quad$ Full-time Tenure-track & .244 & 1.263 & .210 & 4.458 \\
$\quad$ Full-time and Part-time & .125 & .615 & .540 & 4.937 \\
$\quad$ Nontenure-track & & & & \\
Rank & .163 & .925 & .357 & 3.714 \\
$\quad$ Instructor & .264 & 1.363 & .177 & 4.497 \\
$\quad$ Assistant Professor & -.030 & -.251 & .802 & 1.677 \\
$\quad$ Associate Professor & & & & \\
$\quad$ Gender & .367 & 2.414 & .018 & 2.763 \\
$\quad$ Female & .089 & .702 & .484 & 1.921 \\
$\quad$ Other & & & & \\
Age & -.203 & -1.613 & .111 & 1.905
\end{tabular}




$\begin{array}{lrrrr}\text { 40-49 years } & .117 & .910 & .366 & 1.983 \\ \text { 60+ years } & .149 & 1.269 & .208 & 1.645 \\ \quad \text { Refused } & -.091 & -.653 & .516 & 2.315 \\ \quad & & & & \\ \quad \begin{array}{l}\text { Femaction variables } \\ \text { Femalle x Full-time Tenure-track }\end{array} & -.425 & -2.732 & .008 & 2.893 \\ \begin{array}{l}\text { time Nontenure-Track } \\ \text { Assistant Professor x 40-49 age }\end{array} & -.425 & -2.455 & .016 & 3.576 \\ \end{array}$

Note: Dependent variable: Willingness to complete in-person training on the CMS.

For the in-person final model, the ANOVA was statistically significant ( $F=2.242$ at 15 df., $p=0.010)$, so the model was interpreted. This model demonstrates that of the independent variables, only compatibility was significantly positively associated with willingness to complete training in-person (standardized $\beta=0.242, p=0.016$ ).

For this study, compatibility was defined as the degree to which faculty members perceive the CMS as consistent with their existing values, past experiences, and current or future teaching needs. Because in multivariate analysis, compatibility was the only independent variable statistically significantly associated with willingness to complete training on the CMS, both online and in-person, a bivariate analysis of the mean compatibility score for each mediating variable category was conducted. Table 10 provides a summary of this analysis.

Table 10

Descriptive Analysis of Compatibility Scores

\begin{tabular}{|c|c|c|c|}
\hline Category & Levels & n (\%) & $\begin{array}{l}\text { Compatibility Score } \\
(M, S D)\end{array}$ \\
\hline All & All & $102,(100 \%)$ & $3.66(.73)$ \\
\hline \multirow[t]{3}{*}{ Gender } & Male & $48,(47 \%)$ & $3.71,(.66)$ \\
\hline & Female & $46,(45 \%)$ & $3.67,(.75)$ \\
\hline & Other & $8,(8 \%)$ & $3.38,(1.41)$ \\
\hline \multirow[t]{5}{*}{ Age Group } & 20-39 years & 19, (19\%) & $3.68,(.72)$ \\
\hline & 40-49 years & $22,(22 \%)$ & $3.80,(.62)$ \\
\hline & $50-59$ years & $25,(25 \%)$ & $3.74,(.70)$ \\
\hline & $60+$ years & $21,(21 \%)$ & $3.56,(.78)$ \\
\hline & Refused & $15,(15 \%)$ & $3.43,(.87)$ \\
\hline \multirow[t]{3}{*}{ Tenure Status } & Full-time Tenured & 46, (45\%) & $3.54,(.81)$ \\
\hline & Full-time Tenure-track & $24,(24 \%)$ & $3.65,(.60)$ \\
\hline & $\begin{array}{l}\text { Full time and Part-time } \\
\text { Non-tenure-track }\end{array}$ & $32,(31 \%)$ & 3.84, (.67) \\
\hline \multirow[t]{3}{*}{ Rank } & Instructor & $27,(26 \%)$ & $3.95,(.65)$ \\
\hline & Assistant Professor & $24,(24 \%)$ & $3.68,(.58)$ \\
\hline & Associate Professor & 23, (23\%) & $3.59,(.68)$ \\
\hline
\end{tabular}




\begin{tabular}{llll}
\multirow{3}{*}{ Department } & Professor & $28,(27 \%)$ & $3.42,(.87)$ \\
& STEM & $35,(34 \%)$ & $3.87,(.42)$ \\
& SEHP & $16,(16 \%)$ & $3.68,(.76)$ \\
& ECG & $15,(15 \%)$ & $3.41,(.67)$ \\
& Other & $36,(35 \%)$ & $3.56,(.73)$
\end{tabular}

Note: STEM = Science, Technolgy, Engineering, and Mathmatics. SEHP = Social Science, Economics, History, and Political Science. ECG = Education, Communication, and Game Design. Other includes Business Administration, English Studies, Industrial Technology, Interdisciplinary Studies, and Nursing.

As shown in Table 10, most mediating variable levels were not considerably different with respect to mean compatibility scores. However, for tenure status there was a trend toward lower compatibility scores associated with higher tenure status (full-time tenured $=3.54$, fulltime tenure-track $=3.65$, full-time and part-time non-tenure-track $=3.84$ ). Similarly, for rank, mean compatibility scores decreased as ranks increased (instructor $=3.95$, assistant professor $=$ 3.68 , associate professor $=3.59$, professor $=3.42$ ).

Table 9 also indicates that the mean compatibility score for males was slightly higher than for females (3.71 vs. 3.67), and the respondents who did not report their gender scored much lower than the two other groups (3.38). Generally, as age increased, mean compatibility scores decreased. Excepting those in the 20-39 year old range who scored less than the 40-49 and 50-59 age groups levels $(20-39$ years $=3.68,40-49$ years $=3.80,50-59$ years $=3.74$, and $60+$ years $=3.56$ ). Like gender, participants who chose to not report their age scored the lowest in compatibility (3.43). Faculty members in the Science, Technology, Engineering, and Mathematics and Social Science, Economics, History, and Political Science departments reported the highest mean compatibility scores, followed by faculty members in the Other (included Business Administration, English Studies, Industrial Technology, Interdisciplinary Studies, and Nursing) group and the Education, Communication, and Game Design departments (Science, Technology, Engineering, and Mathematics $=3.87$, Social Science, Economics, History, and Political Science $=3.68$, Education, Communication, and Game Design $=3.41$, Other = 3.56).

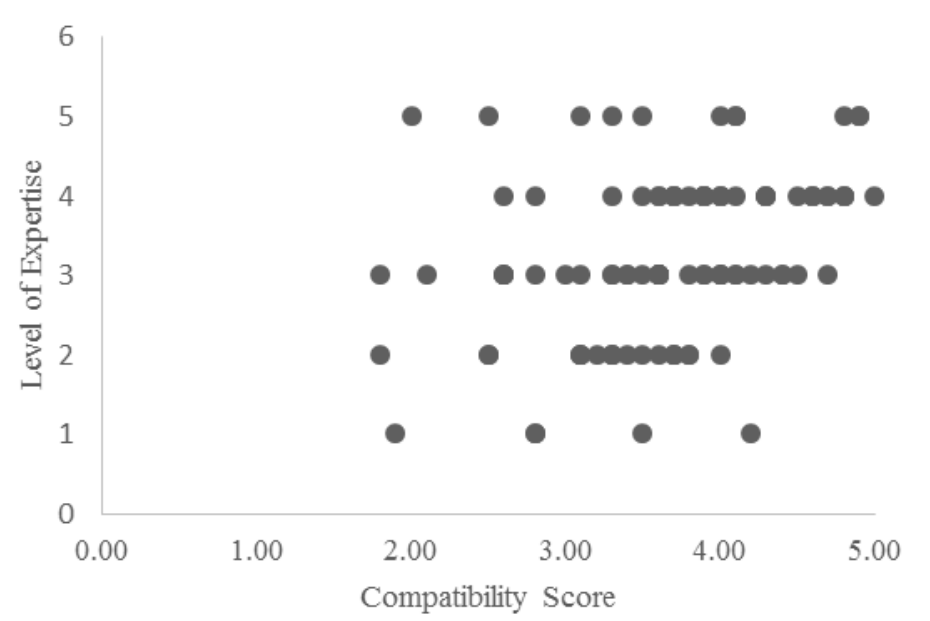

Figure 1. Scatterplot of compatibility score by level of expertise. Scale 1-5, where $1=$ not at all willing, $2=$ somewhat unwilling, 3 = neither willing nor unwilling, 4 = somewhat willing, and 5 = very willing. 




Figure 2. Scatterplot of compatibility score by length of use. $0=$ less than 1 year or no use of CMS.

Self-rated level of expertise was also positively associated with compatibility score $(r=$ $.593, p<0.01$, see Figure 1). In addition, there was a moderate positive correlation between length of CMS use in years and compatibility perceptions ( $r=.546, p<0.01$, see Figure 2$)$.

\section{Discussion}

\section{Key Findings Summary}

Of the independent variable measurements, only compatibility was significantly associated with willingness to complete training (both in-person and online). Consequently, the study results suggest that the other independent variables (relative advantage, complexity, trialability, and observability) did not significantly influence willingness to complete training on the CMS. Bivariate analyses indicated that higher tenure status was associated with lower perceptions of compatibility, and, similarly, that faculty perceptions of compatibility increased as their ranks decreased. Participants who rated themselves as having higher expertise levels also had the highest perceptions of compatibility. Lastly, in most cases, faculty members that used the CMS longer had higher perceptions of compatibility with the CMS than those that used the CMS for a shorter period of time.

Faculty members who perceived the CMS as compatible with their teaching styles were more willing to complete CMS training. For that reason, a strategy that can be used by universities is to identify and work with faculty members who view the CMS as incompatible with their teaching styles to help them discover methods to integrate the CMS into their classroom activities. This will likely not only increase willingness to engage in CMS training but will also promote CMS adoption.

Results of this study also revealed that faculty members who rated themselves as having a high level of expertise in using the CMS preferred online training. On the other hand, faculty members with lower expertise levels preferred in-person training. Faculty who reported lower expertise levels may benefit from assistance with integrating the CMS into their instruction as 
well as from technical help. Therefore, universities that design in-person CMS training for faculty members with low expertise levels and online training for faculty with higher expertise levels will likely increase faculty willingness to complete training on the CMS.

\section{Connection to the Literature}

In this study, compatibility was found to significantly positively influence faculty willingness to complete CMS training, both online and in-person. Although previous researchers did not specifically explore how perceptions of compatibility impact faculty willingness to complete training, they studied its influence on faculty willingness to adopt instructional technology. The findings of this study are generally consistent with the findings of other researchers. For instance, Tabata and Johnsrud (2008) found that if faculty members believe that distance education is compatible with their working styles then they are likelier to instruct distance education classes, and Sayadian et al.'s (2009) results suggested that if faculty members perceive that web-based instruction is consistent with their values and teaching methods then they are more disposed to integrating web-based instruction in their courses. Also, Tornatzky and Klein (1982), who studied general IT adoption, found that compatibility perceptions delivered one of the most constant, significant, positive associations within a large variety of innovation categories.

The findings of this research suggest that relative advantage did not significantly influence faculty willingness to complete CMS training, either positively or negatively. Although other studies did not specifically research how perceptions of relative advantage influence faculty willingness to complete training, researchers studied it in relation to faculty adoption and use of IT in the classroom. The findings of this study are inconsistent with prior research that found either positive or negative relationships. For example, Aremu et al. (2013) and Sayadian et al. (2009) found that relative advantage positively impacts faculty IT adoption, and Bennett and Bennet's (2003) research suggested that relative advantage positively influences faculty training program effectiveness. Conversely, Tabata and Johnsrud (2008) found an association between relative advantage and a decreased use of new technology practices. According to Tabata and Johnsrud, this may be because while faculty members perceive that distance education affords a relative advantage over current approaches, they do not believe that distance education instruction coincides with their responsibilities, needs, or values. Faculty members at FSU may have lacked a concept of courses without Blackboard. This is because most faculty members have adopted Blackboard for at least basic functions. Since Blackboard is widely adopted in at least some way, it may have been difficult for faculty members to gauge the "relative" advantage of not using it, given that it is rarely rejected completely at FSU in practice. This may explain why the results from this study differ from previous research.

This study found that perceptions of complexity do not significantly influence instructor willingness to complete CMS training. Previous research has not focused on how perceptions of the complexity of IT influences willingness to complete training, like this study. Rather, it has focused on how it affects faculty member willingness to use IT. The results of this research are consistent with studies conducted by Tabata and Johnsrud (2008) and Wang (2009). These studies found no significant relationship between faculty adoption of IT and complexity perceptions. Yet, these results contradict other study findings which suggested there is a significant inverse relationship between faculty IT adoption and complexity perceptions 
((Bennett \& Bennett, 2003; Keesee \& Shepard, 2011; Motaghian, Hassanzadeh, \& Moghadam, 2013; Prescott \& Conger, 1995). Perhaps complexity has a strong impact only when faculty members perceive that the CMS is complex. Faculty members have used the Blackboard CMS at FSU for over 10 years, and Blackboard has been upgraded and improved over that time (Green, 2010). These advances may have lowered FSU faculty perceptions of its complexity to the extent that it was not much of an influence.

The findings of this study suggest that faculty perceptions of trialability do not significantly affect willingness to complete CMS training. Although previous studies did not focus on how perceptions of trialability influence faculty willingness to complete CMS training, they did focus on its influence of faculty willingness to use instructional technology. For example, Sayadian et al. (2009) suggested that faculty perceptions of trialability positively affects their incorporation of online instruction. Bennett and Bennett (2003) asserted that faculty members should be permitted to try IT in order to foster use, and Tabata and Johnsrud (2008) found that permitting faculty members to try instructional technology increased their adoption of it in distance education. It may be that trialability of the Blackboard CMS at FSU is not as critical to faculty because it has become much easier to edit courses in Blackboard. This is because, over time, Blackboard has become more functional (Blackboard, Inc., 2015).

This study found that faculty perceptions of observability do not significantly influence willingness to complete CMS training. This is in contradiction to previous findings. In particular, the results of three studies noted earlier (Bennett \& Bennett, 2003; Sayadian et al., 2009; Tabata \& Johnsrud, 2008) suggested that when faculty members thought their efforts would be observable, they would more likely to adopt IT. At FSU, although extensive adoption of all the functions of Blackboard is likely not occurring, at least some of its functions are being used in the majority of FSU classes. Therefore, the failure to use Blackboard altogether would become obvious to colleagues or students. Therefore, since observability is already consistently high, it may not influence willingness to complete CMS training. Although it may pressure faculty members to increase their Blackboard use, it does not directly result in increased willingness to complete training.

\section{Findings Related to Theoretical Framework}

This study was framed using components of the DOI theory. As conceptualized by Rogers (2003), the DOI theory suggests that perceived relative advantage, compatibility, trialability, and observability of an innovation positively influences its adoption rate, while perceived complexity negatively influences its adoption rate. Of the five attributes, only compatibility was related to faculty willingness to complete training on their institution's CMS, and this was a significantly positive relation for both online and in-person training. This coincides with Roger’s (2003) theory.

Though perceptions of relative advantage, complexity, trialability, and observability may be influential in general for the adoption of technology as Rogers' (2003) postulated, there were no associations for this study's dependent variables (willingness of faculty to complete online and in-person training on the CMS) and for this technology (CMS). Perceptions of relative advantage may not have influenced faculty willingness to complete CMS training because Blackboard (in at least some capacity) is already used by most FSU faculty. Therefore, 
instructors may have had difficulty determining the "relative" situation of not using Blackboard. Regarding complexity, it is probable that FSU faculty did not perceive it to be relatively complex, given the high level of complexity of other current technology. Similarly, because CMSs, like Blackboard, permit faculty members to easily modify actions they take in the CMS, trialability may not be an important factor in their decisions to complete training. Similarly, in this study, observability did not influence willingness to complete CMS training, possibly because adoption of the CMS at FSU is already quite observable.

\section{Study Limitations}

This study is not without limitations. The results of this study are potentially generalizable to faculty members who teach at other state universities in the US. They are particularly generalizable to campuses that teach undergraduate and graduate students, have a faculty base similar to that of FSU, and have a CMS. However, the results may not be generalizable to other types of faculties and other settings. In addition, it is possible that the five perceived attributes associated with diffusion of innovation theory are not the most optimal attributes to explain willingness to complete training on a CMS in this population. Furthermore, the instrument used to measure the diffusion of innovation perceptions may not have been ideal. Furthermore, the best-subsets modeling approach may not have been the optimal choice for modeling, but sensitivity analysis showed that other approaches yielded similar results (Pereira, 2015), so the results are felt to be robust. Future research should consider other types of faculties in other settings, and measure other predictors felt to influence willingness to complete training on their CMS.

\section{Conclusion and Recommendations}

In conclusion, overall, the faculty in this study did not express high levels of willingness to complete CMS training, but CMS compatibility with teaching style was an influence. This study suggests that training for higher education faculty members on their institution's CMS should not be "one size fits all.” Proper evaluation and categorization of teaching styles, as well as current utilization of the CMS are necessary before developing appropriate online and inperson training programs. This evaluation will help universities to better administer effective training that accommodates faculty members with different philosophies and pedagogical approaches to teaching as well as different perceived expertise levels. Further, it will foster enhanced and regular use of the institution's already-implemented CMS. More universal adoption by higher education faculty members of their institution's CMS will undoubtedly lead to an overall improvement in the quality of teaching and learning in higher education.

\section{References}

Abrahams, D. A. (2010). Technology adoption in higher education: A framework for identifying and prioritising issues and barriers to adoption of instructional technology. Journal of Applied Research in Higher Education, 2(2), 34-49. http://doi.org/10.1108/17581184201000012 
Allen, I. E., \& Seaman, J. (2012). Digital faculty: Professors, teaching and technology, 2012. Babson Park, MA: Babson Survey Research Group. Retrieved from http://www.babson.edu/Academics/faculty/provost/Pages/babson-survey-researchgroup.aspx

Al-Senaidi, S., Lin, L., \& Poirot, J. (2009). Barriers to adopting technology for teaching and learning in Oman. Computers \& Education, 53(3), 575-590. http://doi.org/10.1016/j.compedu.2009.03.015

Archambault, L., Wetzel, K., Foulger, T. S., \& Williams, M. K. (2010). Professional development 2.0: Transforming teacher education pedagogy with 21st century tools. Journal of Digital Learning in Teacher Education, 27(1), 4-11. http://doi.org/10.1080/21532974.2010.10784651

Aremu, A., Fakolujo, O., \& Oluleye, A. (2013). Designing and Developing e-content in higher education: The University of Ibadan model. In Unlocking the potential of ICT in higher education: Case studies of educational technology initiatives at African universities (pp. 76-88). Johannesburg, South Africa: South African Institute for Distance Education. Retrieved from http://www.saide.org.za/

Bennett, J., \& Bennett, L. (2003). A review of factors that influence the diffusion of innovation when structuring a faculty training program. The Internet and Higher Education, 6(1), 53-63. http://doi.org/10.1016/S1096-7516(02)00161-6

Blackboard, Inc. (2017). Learn how Blackboard can help you grow in the evolving market of higher education. Retrieved from http://www.blackboard.com/highereducation/index.aspx

Bothma, C. H., \& Cant, M. C. (2011). Adopting learning technologies: From belief to practice. Educational Studies, 37(4), 375-389. http://doi.org/10.1080/03055698.2010.511697

Calderon, O., Ginsberg, A. P., Ciabocchi, L., Calderon, O., Ginsberg, A. P., \& Ciabocchi, L. (2012). Multidimensional assessment of pilot blended learning programs: Maximizing program effectiveness based on student and faculty feedback. Journal of Asynchronous Learning Networks, 16(4), 23-37. http://doi.org/http://sloanconsortium.org/publications/jaln_main

Carril, P. C. M., Sanmamed, M. G., \& Sellés, N. H. (2013). Pedagogical roles and competencies of university teachers practicing in the e-learning environment. The International Review of Research in Open and Distance Learning, 14(3), 462-487. http://doi.org/http://www.irrodl.org/index.php/irrodl

Chen, J. C., Ellis, M., Lockhart, J., Hamoush, S., Brawner, C. E., \& Tront, J. G. (2000). Technology in engineering education: What do the faculty know and want? Journal of Engineering Education, 89(3), 279-283. http://doi.org/10.1002/j.2168$\underline{\text { 9830.2000.tb00526.X }}$ 
Chitiyo, R., \& Harmon, S. W. (2009). An analysis of the integration of instructional technology in pre-service teacher education in Zimbabwe. Educational Technology Research and Development, 57(6), 807-830. http://doi.org/10.1007/s11423-009-9136-7

deNoyelles, A., Cobb, C., \& Lowe, D. (2012). Influence of reduced seat time on satisfaction and perception of course development goals: A case study in faculty development. Journal of Asynchronous Learning Networks, 16(2), 85-98. http://doi.org/http://sloanconsortium.org/publications/jaln_main

Ertmer, P. A., \& Ottenbreit-Leftwich, A. T. (2010). Teacher technology change: How knowledge, confidence, beliefs, and culture intersect. Journal of Research on Technology in Education, 42(3), 255-284. http://doi.org/10.1080/15391523.2010.10782551

Goktas, Y., Yildirim, S., \& Yildirim, Z. (2009). Main barriers and possible enablers of ICTs integration into pre-service teacher education programs. Educational Technology \& Society, 12(1), 193-204. http://doi.org/http://www.ifets.info/

Green, K. C. (2010). The 2010 campus computing survey. Retrieved from http://www.campuscomputing.net/survey

Hassan, S. S. (2011). The needs and perceptions of academics regarding their professional development in an era of educational transformation. South African Journal of Higher Education, 25(3), 476-490. http://doi.org/http://jolt.merlot.org/

Hicks, S. D. (2011). Technology in today's classroom: Are you a tech-savvy teacher? Clearing House: A Journal of Educational Strategies, Issues and Ideas, 84(5), 188-191. http://doi.org/http://journalseek.net/cgibin/journalseek/journalsearch.cgi?field=issn\&query=0009-8655

Hixon, E., Buckenmeyer, J., Barczyk, C., Feldman, L., \& Zamojski, H. (2012). Beyond the early adopters of online instruction: Motivating the reluctant majority. The Internet and Higher Education, 15(2), 102-107. http://doi.org/10.1016/j.iheduc.2011.11.005

Hosmer, D. W., Borko, J., \& Lemeshow, S. (1989). Best subsets logistic regression. Biometrics, 45, 1265-1270. http://doi.org/10.2307/2531779

Hurtado, S., Eagan, K., Pryor, J. H., Whang, H., \& Tran, S. (2012). Undergraduate teaching faculty: The 2010-2011 HERI faculty survey. University of California, Los Angeles: Higher Education Research Institute. Retrieved from http://www.heri.ucla.edu/

Iorio, J., Kee, K., \& Decker, M. (2012). Instructional technology training: Developing functional and applied skill sets. In Proceedings of the Society for Information Technology \& Teacher Education International Conference (pp. 1188-1193). Chesapeake, VA. Retrieved from http://www.editlib.org/p/39740/ 
Keengwe, J., Kidd, T., \& Kyei-Blankson, L. (2009). Faculty and technology: Implications for faculty training and technology leadership. Journal of Science Education and Technology, 18(1), 23-28. http://doi.org/10.1007/s10956-008-9126-2

Keesee, G. S. (2010). A perceived attributes and organizational support influencing course management system adopter status in historically black colleges and universities (Doctoral dissertation). Retrieved from ProQuest, UMI Dissertations Publishing. (Order No. 3426608).

Keesee, G. S., \& Shepard, M. (2011). Perceived attributes predict course management system adopter status. Online Journal of Distance Learning Administration, 14(1). Retrieved from http://www.westga.edu/ distance/ojdla/

Kidd, T. T. (2010). Butterfly under a pin: Exploring the voices and stories told of faculty who adopt ICT's for teaching and learning practices. Education and Information Technologies, 15(3), 155-170. http://doi.org/10.1007/s10639-009-9102-3

King, J., E. (2003). Running a best-subsets logistic regression: An alternative to stepwise methods. Educational and Psychological Measurement, 63(3), 392-403. http://doi.org/10.1177/0013164403063003003

Kinuthia, W. (2005). Planning faculty development for successful implementation of web-based instruction. Campus-Wide Information Systems, 22(4), 189-200. http://doi.org/10.1108/10650740510617502

Korr, J., Derwin, E. B., Greene, K., \& Sokoloff, W. (2012). Transitioning an adult-serving university to a blended learning model. The Journal of Continuing Higher Education, 60(1), 2-11. http://doi.org/10.1080/07377363.2012.649123

Mallinson, B., \& Krull, G. (2013). An investigation of the deployment of the Moodle virtual learning environment at eight African universities. In Unlocking the potential of ICT in higher education: Case studies of educational technology initiatives at African universities (pp. 30-45). Johannesburg, South Africa: South African Institute for Distance Education. Retrieved from http://www.saide.org.za/

Mark, K., Thadani, D. R., Santandreu Calonge, D., Pun, C. F. K., \& Chiu, P. H. P. (2011). From neophyte to experienced facilitator: An interactive blended-learning course for graduate teaching assistants in Hong Kong. Knowledge Management \& E-Learning: An International Journal, 3(2), 153-169. http://doi.org/http://www.kmeljournal.org/ojs/index.php/online-publication

Masalela, R. K. (2009). Potential benefits and complexities of blended learning in higher education: The case of the University of Botswana. Turkish Online Journal of Distance Education, 10(1), 66. http://doi.org/http://tojde.anadolu.edu.tr/ 
McBride, R., \& Thompson, A. (2011). Using Moodle Academy to prepare technical college faculty for online teaching: An evaluation model. In Proceedings of the Society for Information Technology \& Teacher Education International Conference (pp. 513-518). Chesapeake, VA. Retrieved from http://www.editlib.org/p/36320/

McKissic, S. C. (2012). Examining transformative faculty development factors to advance technology adoption and diffusion at a campus-based institution. (Doctoral dissertation). Retrieved from ProQuest, UMI Dissertations Publishing. (Order No. 3095210)

Meyer, K. A. (2014). An analysis of the cost and cost-effectiveness of faculty development for online teaching. Journal of Asynchronous Learning Networks, 18(1). Retrieved from http://sloanconsortium.org/publications/jaln_main

Motaghian, H., Hassanzadeh, A., \& Moghadam, D. K. (2013). Factors affecting university instructors' adoption of web-based learning systems: Case study of Iran. Computers \& Education, 61, 158-167. http://doi.org/10.1016/j.compedu.2012.09.016

Newhouse, R., Buckley, K. M., Grant, M., \& Idzik, S. (2013). Reconceptualization of a doctoral EBP course from in-class to blended format: lessons learned from a successful transition. Journal of Professional Nursing, 29(4), 225-232. http://doi.org/10.1016/j.profnurs.2012.05.019

Onyia, C. R., \& Onyia, M. (2011). Faculty perception for technology integration in Nigeria university system: Implications for faculty quality curriculum design. International Journal of Business and Social Science, 2(1), 81-92. http://doi.org/http://www.ijbssnet.com/

Pereira, A. S. (2015). Faculty willingness to complete information technology training on course management systems (Doctoral dissertation). Retrieved from Proquest, UMI Dissertation Publishing. (Order No. 3700990).

Porter, G. (2011). Specifics of course management system benefits for new university faculty. Higher Education Studies, 1(2), 2-7. http://doi.org/10.5539/hes.v1n2p2

Potter, S. L., \& Rockinson-Szapkiw, A. J. (2012). Technology integration for instructional improvement: The impact of professional development. Performance Improvement, 51(2), 22-27. http://doi.org/10.1002/pfi.21246

Prescott, M. B., \& Conger, S. A. (1995). Information technology innovations: A classification by IT locus of impact and research approach. SIGMIS Database, 26(2-3), 20-41. http://doi.org/10.1145/217278.217284

Rocca, S. J. (2010). Determining the professional development needs of faculty in a college of agriculture. College Student Journal, 54(1), 69-75. http://doi.org/http://www.projectinnovation.biz/csj.html 
Rogers, E. M. (2003). Diffusion of innovations (5th ed.). New York, NY: Free Press.

Roman, T., Kelsey, K., \& Lin, H. (2010). Enhancing online education through instructor skill development in higher education. Online Journal of Distance Learning Administration, 13(4). Retrieved from http://www.westga.edu/ distance/ojdla/

Samarawickrema, G., \& Stacey, E. (2007). Adopting web-based learning and teaching: A case study in higher education. Distance Education, 28(3), 313-333.

http://doi.org/10.1080/01587910701611344

Sandford, B. A., Dainty, J. D., Belcher, G. G., \& Frisbee, R. L. (2011). Perceptions of the willingness of part-time instructors in community colleges in the US to engage in professional development opportunities and the best method(s) of delivering these experiences. Journal of Career and Technical Education, 26(1), 48-61. http://doi.org/http://scholar.lib.vt.edu/ejournals/JCTE/

Sayadian, S., Mukundan, J., \& Baki, R. (2009). Exploring the factors influencing UPM English language faculty members' adoption and integration of web-based instruction (WBI). Journal of College Teaching \& Learning, 6(6), 31-38. http://doi.org/http://journals.cluteonline.com/index.php/TLC

Simon, D., Jackson, K., \& Maxwell, K. (2013). Traditional vs. online instruction: Faculty resources impact strategies for course delivery. Business Education \& Accreditation, 5(1), 107-116. http://doi.org/http://www.theibfr.com/bea.htm

Smolin, L., \& Lawless, K. A. (2011). Evaluation across contexts: Evaluating the impact of technology integration professional development partnerships. Journal of Digital Learning in Teacher Education, 27(3), 92-98. http://doi.org/10.1080/21532974.2011.10784663

Tabata, L. N., \& Johnsrud, L. K. (2008). The impact of faculty attitudes toward technology, distance education, and innovation. Research in Higher Education, 49(7), 625-646. http://doi.org/10.1007/s11162-008-9094-7

Tornatzky, L. G., \& Klein, K. J. (1982). Innovation characteristics and innovation adoptionimplementation: A meta-analysis of findings. IEEE Transactions on Engineering Management, EM-29(1), 28-45. http://doi.org/10.1109/TEM.1982.6447463

Tsai, Y., \& Talley, P. C. (2013). The effect of a course management system (CMS)-supported strategy instruction on EFL reading comprehension and strategy use. Computer Assisted Language Learning, 1-17. http://doi.org/10.1080/09588221.2012.757754

Unal, Z., \& Unal, A. (2011). Evaluating and comparing the usability of web-based course management systems. Journal of Information Technology Education: Research, 10(1), 19-38. http://doi.org/http://www.informingscience.us/icarus/journals/jiteresearch 
Unwin, T., Kleessen, B., Hollow, D., Williams, J. B., Oloo, L. M., Alwala, J., ... Muianga, X. (2010). Digital learning management systems in Africa: Myths and realities. Open

Learning, 25(1), 5-23. http://doi.org/10.1080/02680510903482033

Wang, W.-T., \& Wang, C.-C. (2009). An empirical study of instructor adoption of web-based learning systems. Computers \& Education, 53(3), 761-774.

http://doi.org/10.1016/j.compedu.2009.02.021

West, R., Waddoups, G., \& Graham, C. (2007). Understanding the experiences of instructors as they adopt a course management system. Educational Technology Research \& Development, 55(1), 1-26. http://doi.org/10.1007/s11423-006-9018-1

Yidana, I., Sarfo, F. K., Edwards, A. K., Boison, R., \& Wilson, O. A. (2013). Using the Moodle learning management system for teaching and learning at the University of Education, Winneba. In Unlocking the potential of ICT in higher education: Case studies of educational technology initiatives at African universities (pp. 58-75). Johannesburg, South Africa: South African Institute for Distance Education. Retrieved from http://www.saide.org.za/

Yohon, T., \& Zimmerman, D. (2006). An exploratory study of adoption of software and hardware by faculty in the liberal arts and sciences. Journal of Technical Writing and Communication, 36(1), 9-27. http://doi.org/10.2190/8QGV-RYXQ-VY7Q-5RJT 